\title{
Comparative Analgesic and Anti-inflammatory Activities of Two Polyherbal Tablet Formulations (Aujaie and Surangeen) in Rats
}

\author{
MS Akhtar ${ }^{1}$, A Malik ${ }^{1}$, MS Saleem ${ }^{1}$ and G Murtaza ${ }^{2 *}$ \\ ${ }^{1}$ Faculty of Pharmacy, University of Sargodha, Sargodha, ${ }^{2}$ Department of Pharmaceutical Sciences, COMSATS Institute of \\ Information Technology, Abbottabad 22060, Pakistan.
}

*For correspondence: Email: gmdogar356@gmail.com; Tel: +92-314-2082826; Fax: +92-992-383441

Received: 17 July 2012

Revised accepted: 26 June 2013

\begin{abstract}
Purpose: To investigate the analgesic and anti-inflammatory activities of two herbal polymedicines Aujaie and Surangeen to ascertain their therapeutic claims.

Methods: A total of 96 rats were divided into two equal groups; one for determination of antiinflammatory activity and the other for analgesic activity. Anti-inflammatory and analgesic activities were evaluated by carrageenan-induced paw edema and formalin-induced paw licking test, respectively. For both studies, group I (untreated control) received $1 \mathrm{ml} / \mathrm{kg}$, (po) of gum suspension $1 \mathrm{~h}$ before carrageenan injection. Aspirin (100 mg/kg, po) was given to group II (treated control) before injection. Groups III, IV and V were administered orally aujaie (3, 4 and $5 \mathrm{mg} / \mathrm{kg}$, po, respectively), while surangeen tablets $(10,20$ and $40 \mathrm{mg} / \mathrm{kg}$, po) were given to groups VI, VII and VIII, respectively. Pain was experimentally induced by injecting $0.1 \mathrm{ml}$ of $2.5 \%$ formalin (40\% formaldehyde in distilled water) via the subplantar region of the left hind paw.

Results: Significant $(p<0.05)$ anti-inflammatory activity for aspirin (group II as well as for groups III VIII with paw edema inhibition (PDI) ranging from $24.6-90.2 \%$, There was significant $((p<0.05)$ analgesic activity in group II, VI and VII while in groups III - V and VIII the activity was insignificant $(p<$ 0.05).

Conclusion: Aujaie and surangeen tablets exhibited pronounced analgesic and anti-inflammatory activities in rats depending on the dose employed.
\end{abstract}

Keywords: Aujaie, Surangeen, Anti-inflammatory, Analgesic.

Tropical Journal of Pharmaceutical Research is indexed by Science Citation Index (SciSearch), Scopus, International Pharmaceutical Abstract, Chemical Abstracts, Embase, Index Copernicus, EBSCO, African Index Medicus, JournalSeek, Journal Citation Reports/Science Edition, Directory of Open Access Journals (DOAJ), African Journal Online, Bioline International, Open-J-Gate and Pharmacy Abstracts

\section{INTRODUCTION}

In Pakistan, Hakims (herbal practitioners) use various local herbal polypharmaceutical preparations for the treatment of different types of rheumatic diseases. Although the use of these products has a sound tradition and rational background according to herbal system of medicine, it is essential to investigate the validity by scientific methods [1-5]. Such studies can help to determine their therapeutic usefulness. Aujaie and Surangeen tablets tablets have been used in traditional (Unani) system of medicine for the treatment of inflammation and pain associated with rheumatoid arthritis and osteoarthritis [6]. Surangeen tablet is a herbal polypharmaceutical formulation containing extracts of 6 medicinal plants. Each tablet contains Withania somnifera $31.79 \quad \mathrm{mg}$, Colchicum luteum 31.79 mg, Styrax Benzoin 
Dryand $31.79 \mathrm{mg}$, Ammonium chloride $31.79 \mathrm{mg}$, Terminalia chebula $31.79 \mathrm{mg}$ and Smilax china $31.79 \mathrm{mg}$ [6]. Aujaie tablet is another herbal polypharmaceutical formulation containing extracts of 9 medicinal plants. Each tablet contains Calchicum luteum $25 \mathrm{mg}$, Withania somnifera $20 \mathrm{mg}$, Zingeber officinalis $20 \mathrm{mg}$, Aloe indica $10 \mathrm{mg}$, Curculigo orchioides $10 \mathrm{mg}$, Ptychotis ajowan (Ajwain) $10 \mathrm{mg}$, Pimpinella anisum $10 \mathrm{mg}$, Balsamodendron mukul $5 \mathrm{mg}$ and Pistacia lentiscus $5 \mathrm{mg}$ [5-7].

Therefore, the objective of this study was to evaluate and compare the anti-inflammatory and analgesic activities of the aforementioned two herbal poly-pharmaceutical preparations in rats.

\section{EXPERIMENTAL}

\section{Materials}

Aspirin (Reckitt Benckiser, Pakistan) and formalin (37\% formaldehyde solution, Merck, Germany) were purchased from local pharmacy (Servier Pharmacy, Sargodha). Carrageenan (Sigma, USA) and gum tragacanth (Merck, Germany) were procured through local sources (Ahmad Dealers, Lahore). The tested herbal poly-pharmaceutical tablet preparations aujaie (Hamdard Laboratories, Karachi, Pakistan) and surangeen (Qarshi Laboratories, Lahore, Pakistan) were purchased from local pharmacy (Servier Pharmacy, Sargodha).

\section{Animals and drug administration}

Wister albino rats of either sex weighing 200-250 $\mathrm{g}$ were used. 96 animals were used, 48 for each experiment, i.e., analgesic and anti-inflammatory studies. These 48 rabbits were sub-grouped as shown in Table 1. The animals were housed in standard polypropylene cages and were kept under controlled room temperature $\left(25 \pm 10^{\circ} \mathrm{C}\right.$, relative humidity $60-70 \%)$ and fed with standard laboratory diet with water ad libitum. Two sets of eight groups of six animals each have been used for the experiments (Table 1). The doses of tablets administered to the animals were selected based on human doses (Table 1) as indicated in Unani literature [3-5]. The animal studies were approved (approval ref no. 33$\mathrm{BP} / 2009 / \mathrm{SU}$ ) by the Departmental Ethical Committee and were conducted according to international guidelines [8] as well as the guidelines of the Institutional Animal Ethical Committee [7].
Table 1: Grouping of experimental animals, and doses of control and test drugs $(n=6)$

\begin{tabular}{lc}
\hline Group & Treatment \\
\hline $\begin{array}{l}\text { Group I (Normal } \\
\text { ontrol) }\end{array}$ & $\begin{array}{l}\text { Gum tragacanth solution (1 } \\
\mathrm{ml} / \mathrm{kg} / \mathrm{p} .)^{\mathrm{a}}\end{array}$ \\
$\begin{array}{l}\text { Group II } \\
\text { (Standard control) }\end{array}$ & Aspirin $(100 \mathrm{mg} / \mathrm{kg}, \text { p.o.) })^{\mathrm{a}, \mathrm{b}, \mathrm{c}}$ \\
$\begin{array}{l}\text { Group III (Aujaie) } \\
\text { Group IV (Aujaie) }\end{array}$ & $3 \mathrm{mg} / \mathrm{kg}$, p.o. \\
Group V (Aujaie) & $4 \mathrm{mg} / \mathrm{kg}$, p.o. \\
$\begin{array}{l}\text { GroupVI } \\
\text { (Surangeen) }\end{array}$ & $5 \mathrm{mg} / \mathrm{kg}$, p.o. \\
$\begin{array}{l}\text { GroupVII } \\
\text { (Surangeen) } \\
\text { GroupVIII } \\
\text { (Surangeen) }\end{array}$ & $10 \mathrm{mg} / \mathrm{kg}$, p.o. \\
\hline
\end{tabular}

Note: ${ }^{a}[7],{ }^{b}[8],{ }^{c}[9]$.

\section{Preparation of solutions}

Freshly prepared suspensions of all test tablets were prepared by suspending tablet powder in $0.5 \%$ suspension of gum tragacanth. $0.5 \%(\mathrm{w} / \mathrm{v})$ suspension of gum tragacanth was prepared by dissolving $0.05 \mathrm{~g}$ of gum tragacanth in $10 \mathrm{ml}$ of distilled water. $1 \%$ (w/v) carrageenan suspension is prepared by dissolving $1 \mathrm{~g}$ of carrageenan in $100 \mathrm{ml}$ of normal saline. $2.5 \%$ formalin solution was prepared by dissolving 6.8 $\mathrm{ml}$ of $37 \%$ formalin in $100 \mathrm{ml}$ of distilled water.

\section{Evaluation of anti-inflammatory activity}

The animals were fasted for $24 \mathrm{~h}$ with free access to water prior to experiments. Approximately $100 \mu \mathrm{l}$ of $1 \%$ carrageenan suspension (prepared $1 \mathrm{~h}$ before each experiment) was injected into the plantar surface of the right hind paw of rat $[9,10]$ and the site of injection was marked.

Rats of group I (control group) received only gum tragacanth solution $1 \mathrm{~h}$ before carrageenan injection. Similarly, aspirin was given to the group II (standard group). Three different doses of each of the two herbal preparations were given orally to groups III, IV, V, VI, VII and VIII, respectively by gastric lavage. The anterio-posterior diameter of the rat paw was measured at 0, 1, 2 and $3 \mathrm{~h}$ intervals after carrageenan injection using vernier calipers (AM13, Emmay, Pakistan) at the marked site. The difference between the basal value of paw diameter and that measured at different time intervals was noted in millimeters and the difference was regarded as degree of edema (inflammation) developed after carrageenan injection [11-16]. Paw edema inhibition (PI) at different doses of test and standard drugs was calculated by comparing with untreated control rats, as in Eq 1 [17].

Trop J Pharm Res, August 2013;12 (4): 604 
$P I(\%)=100\left\{(\mathrm{Vt}-\mathrm{Vo})_{\mathrm{C}}-(\mathrm{Vt}-\mathrm{Vo})_{T}\right\} /(\mathrm{Vt}-\mathrm{Vo})_{\mathrm{c}} \ldots$

where, $V_{t}$ is rat paw volume at time $t, V_{o}$ is initial rat paw volume (basal value), $\left(V_{t}-V_{o}\right)_{c}$ is edema produced in the control group and $\left(\mathrm{V}_{\mathrm{t}}-\mathrm{V}_{\mathrm{O}}\right)_{\mathrm{T}}$ is edema produced in the treatment group.

\section{Evaluation of analgesic activity}

Three different doses of each of the herbal preparations were given orally by gastric lavage to animals of groups III, IV, V, VI, VII and VIII, respectively. Group I and II animals received gum tragacanth and aspirin suspension, respectively. After $1 \mathrm{~h}$, analgesic activity was determined using formalin-induced paw licking test. $100 \mu \mathrm{l}$ of $2.5 \%$ formalin was injected into dorsal surface left hind paw. After injecting formalin, the rats were observed for $30 \mathrm{~min}$ and the number of lickings observed $[19,20]$. Analgesic activity was expressed as "none", "mild" and "good" if reduction in number of lickings was $<20, \geq 20$ but $<40$ and $\geq 40 \%$ of control, respectively [20].

\section{Behavioral pattern studies}

For preliminarily screening of toxic effects of these herbal poly-pharmaceutical preparations, all the treated rats were kept under close observation for one week following the dosing. The symptoms including awareness, mood, motor activity, CNS excitation, posture, motor inco-ordination, muscle tone and reflexes were recorded for 7 days [4]. Any mortality occurring during next two weeks were also recorded.

\section{Statistical analysis}

Anti-inflammatory and analgesic activities were analyzed using Chi-square test with the aid of SPSS, version 13.0 software (IBM, USA), and $p$ $<0.05$ was considered statistically significant.

\section{RESULTS}

\section{Anti-inflammatory activity}

As shown in Table 2, there was significant $(p<$ 0.05 ) anti-inflammatory activity in the aspirin group (group II) at the doses administered. For groups III - VIII, anti-inflammatory activity after 1 $\mathrm{h}$ (paw edema inhibition, PDI) after $1 \mathrm{~h}$ was in the range of $78.58-90.23$ ) and $3 \mathrm{~h}$ and in the range of $24.59-59.0 \%$ ) after $3 \mathrm{~h}$. However after $2 \mathrm{~h}$, anti-inflammatory activity was significant only in groups IV and V with PDI of 44.62 and $63.39 \%$, respectively, but was insignificant $(p<0.05)$ in groups III, VI-VIII with PDI of $12.05-42.60 \%$.

\section{Analgesic activity}

There was significant $(p<0.05)$ analgesic activity (number of paw lickings) in group II but insignificant in groups III - V and VIII $(p<0.05)$ On the other hand, groups VI and VII showed significant $(p<0.05)$ analgesic activity (Table 2$)$.

Table 2: Anti-inflammatory (in carrageenan-induced paw edema) and analgesic activities (no. of paw lickings) of two herbal products in rats

\begin{tabular}{|c|c|c|c|c|c|c|c|c|}
\hline \multirow{3}{*}{ Activity } & & \multicolumn{7}{|c|}{ Treatment } \\
\hline & & \multirow{2}{*}{$\begin{array}{c}\text { Standard drug } \\
\text { Group II }\end{array}$} & \multicolumn{3}{|c|}{ Aujaie } & \multicolumn{3}{|c|}{ Surangeen } \\
\hline & & & Group III & Group IV & Group V & Group VI & $\begin{array}{c}\text { Group } \\
\text { VII }\end{array}$ & Group VIII \\
\hline Edema & $1 \mathrm{~h}$ & 93.91 & 78.58 & 86.26 & 93.64 & 84.73 & 90.23 & 92.87 \\
\hline inhibition (\%) & $2 \mathrm{~h}$ & 65.45 & 12.53 & 44.62 & 63.39 & 12.05 & 41.95 & 42.60 \\
\hline & $3 \mathrm{~h}$ & 52.45 & 24.59 & 52.45 & 50.81 & 24.59 & 37.70 & 59.01 \\
\hline $\begin{array}{l}\text { Number of } \\
\text { lickings } / 0.5 \mathrm{~h}\end{array}$ & & $114 \pm 04$ & $270 \pm 32$ & $204 \pm 30$ & $203 \pm 43$ & $318 \pm 42$ & $303 \pm 19$ & $258 \pm 29$ \\
\hline
\end{tabular}

Table 3: Number of rats treated orally with different doses of the herbal preparations with side effects

\begin{tabular}{|c|c|c|c|c|c|c|}
\hline \multirow{2}{*}{ Toxic/side effect } & \multicolumn{3}{|c|}{ Aujaie } & \multicolumn{3}{|c|}{ Surangeen } \\
\hline & $3 m g / k g$ & $4 m g / k g$ & $5 \mathrm{mg} / \mathrm{kg}$ & $10 \mathrm{mg} / \mathrm{kg}$ & $20 \mathrm{mg} / \mathrm{kg}$ & $40 \mathrm{mg} / \mathrm{kg}$ \\
\hline Dullness & 0 & 1 & 1 & 0 & 1 & 1 \\
\hline Restlessness & 0 & 0 & 0 & 0 & 0 & 0 \\
\hline Diarrhoea & 0 & 1 & 1 & 1 & 0 & 1 \\
\hline Abdominal pain & 0 & 1 & 0 & 0 & 0 & 1 \\
\hline Tremors/shivering & 0 & 0 & 0 & 0 & 0 & 0 \\
\hline Excitement & 0 & 0 & 0 & 0 & 0 & 0 \\
\hline Respiratory distress & 1 & 0 & 1 & 0 & 1 & 1 \\
\hline Coma & 0 & 0 & 0 & 0 & 0 & 0 \\
\hline Death & 0 & 0 & 0 & 0 & 0 & 0 \\
\hline
\end{tabular}


Side effects observed in rats treated orally with different doses of herbal poly-pharmaceutical preparation are presented in Table 3.

\section{DISCUSSION}

One of the most widely used primary tests for screening anti-inflammatory activity of drugs is the carrageenan-induced paw edema in rats [17], while formalin-induced paw licking test has been recommended for screening of analgesic activity. The results obtained in the present investigation indicate the potent anti-inflammatory and analgesic activities of both polyherbal, Aujaie and Surangeen.

For anti-inflammatory activity, both the test herbal drugs were administered orally in the recommended doses and prescribed manner. Anti-inflammatory activity was observed from the very first hour and continued to the end of the test in all animal groups. This activity may probably be due to the inhibition of different aspects and chemical mediators (such as kinin, histamine, and 5-HT) of inflammation as established for aspirin [7,9-14].

The results indicate dose-dependent antiinflammatory activity for both drugs. None to mild anti-inflammatory action of surangeen probably indicates that it was not able to inhibit sufficiently the kinin-like substance responsible for the 2nd hour plateau phase of inflammation [18].

In $3^{\text {rd }}$ hour, both aujaie and surangeen exhibited non-significant anti-inflammatory activity suggesting that they were not able to combat completely prostaglandin release which might be responsible for the last accelerating phase of inflammation as described previously [13]. Histamine and 5-HT are mainly responsible for vasodilatation and increased vascular permeability.

The anti-inflammatory activity of aujaie was not intense in the $2^{\text {nd }}$ and $3^{\text {rd }}$ hour but comparable to that of aspirin indicating that aujaie and aspirin inhibit histamine and serotonin mediated first phase of inflammation but aujaie is less effective in shortening the kinin-mediated plateau interval of $1^{\text {st }}$ phase and the prostaglandin-mediated acceleration phase of inflammation [15]. When kinin release occurs, it activates $\beta_{1}$ and/or $\beta_{2}$ receptors, releasing other inflammatory mediators such as prostaglandins, leukotrienes, histamine, nitric oxide, platelet activating factor and cytokines, among others derived mainly from leucocytes, mast cells, macrophages and endothelial cells, causing either cell influx and plasma extravasations and ultimately prolonging the second phase of inflammation [5]. Therefore, any anti-inflammatory agent that cannot inhibit kinin plateau of $1^{\text {st }}$ phase, will not be able to inhibit $2^{\text {nd }}$ phase of inflammation. It has been reported that the second phase of edema is sensitive to both clinically useful steroidal and non-steroidal anti-inflammatory agents $[18,20]$. This was observed in the positive control whereby aspirin significantly reduced edema.

Pain is associated with the patho-physiology of various clinical conditions such as arthritis, muscular pain, cancer and vascular diseases. Formalin induced paw licking is a suitable method for assessing analgesic activity as it is sensitive for various classes of analgesic drugs, therefore, can be used to clarify possible mechanism of the anti-nociceptive effect of an analgesic. Surangeen showed mild analgesic activity in the same manner as anti-inflammatory activity. Like for anti-inflammatory activity, aujaie exhibited higher analgesic activity than surangeen but less than aspirin.

Formalin test is a biphasic phenomenon involving the direct stimulation of sensory nerve endings that ultimately releases inflammatory mediators such as histamine and serotonin in the late phase. Centrally acting drugs such as opioids inhibit both phases equally but peripherally acting drugs such as aspirin, indomethacin and dexamethasone only inhibit the late phase. The late phase seems to be an inflammatory response with inflammatory pain that can be inhibited by anti-inflammatory drugs [19]. The effect of aujaie on the first and second phase of formalin-induced paw licking suggests that its activity may be due to its central action.

\section{CONCLUSION}

Both surangeen and aujaie showed significant and consistent anti-inflammatory and analgesic activities in experimental rats probably due to the inhibition of release of histamine, serotonin (5$\mathrm{HT}$ ), kinin and prostaglandin. These findings, therefore, support the folkloric use of these polyherbal preparations for the treatment of rheumatism. However, further studies are required to elucidate the exact mechanism(s) of the anti-inflammatory and analgesic activities as well as establish their efficacy and safety for clinical use in rheumatism.

\section{REFERENCES}

1. Laurence LB, John SL, Keith LP. In: Goodman \& Gilman's The Pharmacological Basis of Therapeutics. $11^{\text {th }}$ edn, McGraw-Hill, USA, 2006; pp 1005-1020.

2. Derle DV, Gujar KN, Sagar BSH. Adverse effects associated with the use of non-steroidal anti- 
inflammatory drugs: An overview. Indian J Pharm Sci 2006; 68: 409-441.

3. Warden SJ. Prophylactic Use of NSAIDs by athletes: a risk/benefit assessment. The physician and sports medicine. 2010; 38: 132-138.

4. Katzung BG, Masters BG, Trevor AJ. In: Non steroidal anti-inflammatory drugs. McGraw-Hill publishing company. $9^{\text {th }}$ edition 2004, McGraw-Hill, USA. p. 577-587.

5. Eswar KK, SK Mustan, K Raghunandan Reddy, G Amrender Reddy, N Raghunandan, G Chaitanya. Antiarthritic property of methanolic extract of Syzygium cumini seeds. Int J Integr Biol 2008; 4: 55-61.

6. Monographs of Unani Medicines (Anonymous). National Institute of Health. Volume I, Published by: Drug control and traditional medicine division. 2003, Islamabad, Pakistan. p. 174-175.

7. Muhammad SA, Javed N, Alam SS, Subhani H, Khan $A H$. Evaluation of Aanalgesic activity of Mucuna pruriens Linn. seeds. Prec Soc Exp Biol Med 2008; 22: 69-72.

8. National Research Council. Guide for the care and use of laboratory animals. 8th edn. The National Academies Press, Washington DC, USA, 2011; pp 1-23.

9. Chakraborty $R$, Devi KB, Reta $S$, Sharatchandra $K$, Singh TI. Preliminary studies on anti-inflammatory and analgesic activities of Spilanthes acmella in experimental animal models. Ind $J$ Pharmacol 2004; 36: 148-150.

10. Lakshmi B, Ajith TA, Sheena N, Gunapalan N, Janardhanan KK. Antiperoxidative, antiinflammatory and antimutagenic activities of ethanol extract of the Mycelium of Genoderma lucidum occurring in south India. Teratogen carcinogen Mutagen Suppl 2003; 1: 85-97.

11. Winter CA, Risley EA, Nuss GW. Analgesic activity of extract of Phyllanthus reticulantus. Proc Soc Exp Biol Med 2007; 112: 162-165
12. Saha A, Masud MA, Bachar SC, Kundu JK, Datta BK, Nahar L, Sarker SD. The analgesic and antiinflammatory activities of extracts of Phyllanthus reticulantus in mice model. Pharm Boil 2007; 25: 355-359.

13. Lakshman $\mathrm{SH}$, Kar N, Maurya V, Viswanatha $G L$. Analgesic and anti-inflammatory activity of topical preparation of Lantan camara leaves. Pharmacol Online 2008; 1: 90-96.

14. Okokon JE, Bassey SA, Umoh E. Analgesic and anti inflammatory effects of ethanolic extracts of Hippocratia africana. Int J Pharmacol. 2008; 4: 5155.

15. Guay J, Bateman K, Gordon R, Mancini J, Riendeau D. Carrageenan induced paw edema in rats elicits a predominant prostaglandin E2 (PGE-2) response in the central nervous system associated with the induction of microsomal PGE-2 synthase-1. T Biol Chem 2004; 279: 24866-24872.

16. Ghada-Maria S, Abbott FV. The formalin test in the mouse: a prametric analysis of scoring properties. Pain 2000; 89: 53-63.

17. Di-Rosa M, Giroud PJ, Willoughby DA. Study of the mediator of acute inflammatory response induced in rats in different site by carrageenan and turpine. J Pathol 1971; 101: 15-29.

18. Hong-Mei $X$, Wei $W$, Xiao $Y$, Chang $Y$, Zhang L. Effects and mechanisms of total glucosides of paeony on adjuvant arthritis in rats. J Ethnopharmacol 2007; 109: 442-448.

19. Vinegar R, Scheirber W, Hugo R. Biphasic development of carrageenan edema in rats. J Pharmacol 1969; 150: 328-334.

20. Rosland JH, Tjoisen A, Maehle B, Hole K. The formalin test in mice: effect of formalin concentration. Pain 1990; 42: 235-242. 